NASA-TM-84411 19840002656

\title{
The Growth of Paracoccus halodenitrificans in a Defined Medium
}

Lawrence I. Hochstein and Geraldine A. Tomlinson 


\section{The Growth of Paracoccus halodenitrificans in a Defined Medium}

Lawrence I. Hochstein, Ames Research Center, Moffett Field, California

Geraldine A. Tomlinson, Department of Biology, University of Santa Clara, Santa Clara, California

\section{N/Sก}

National Aeronautics and

Space Administration

Ames Research Center

Moffett Field, California 94035 


\section{ABSTRACT}

A synthetic medium, consisting of inorganic salts and any of a number of carbon sources, supported the aerobic growth of Paracoccus halodenitrificans when supplemented with thiamine. The same medium plus an appropriate nitrogenous oxide supported anaerobic growth when additionally supplemented with methionine. The observation that vitamin $B_{12}$ or betaine replaced methionine suggested that P. halodenitrificans had a defect in the cobalamin-dependent pathway for methionine biosynthesis, as well as the inability to synthesize betaine when growing anaerobically. 


\section{INTRODUCTION}

Paracoccus halodenitrificans is a moderately halophilic denitrifying bacterium isolated by Robinson and Gibbons from a bacon curing brine (Robinson and Gibbons 1952). The organism is thought to have complex growth requirements (Doudoroff 1974), and is grown in media containing protein hydrolysates (Hochstein and Dalton 1968; Forsyth and Kushner 1970; Rosso et al. 1973). While attempting to develop a defined medium for the purpose of examining denitrification during steady-state growth, we observed that a combination of sodium chloride, potassium phosphate, magnesium sulfate, sodium lactate, and trace quantities of yeast extract supported aerobic and anaerobic growth (the latter in the presence of nitrate). This paper identifies thiamine as the factor that supported the aerobic growth of $\underline{P}$. halodenitrificans. The same medium (plus nitrate, nitrite, or nitrous oxide) supported anaerobic growth when supplemented with vitamin $\mathrm{B}_{12}$, betaine, or methionine. After completing this work, we learned of another thiamine-containing defined medium that was suitable for the aerobic growth of $\mathrm{P}$. halodenitrificans (Flannery, W. L., Bacteriol. Proc. 1955. A25).

\section{MATERIALS AND METHODS}

\section{Conditions of growth}

$$
\text { P. halodenitrificans (ATCC 13511) was grown aerobically in 500-ml }
$$

Nephelo flasks (Bellco Glass Co.) containing $50 \mathrm{ml}$ of medium. Aeration was achieved by shaking the flasks on a rotary shaker. Anaerobic growth was carried out in 500-ml Nephelo flasks containing $200 \mathrm{ml}$ of medium and 
modified to permit continuous passage of a gas (usually nitrogen) through a fritted glass disc. The cells were grown at $30^{\circ} \mathrm{C}$ and growth was determined with a Klett-Summerson colorimeter using a blue No. 42 filter. When the turbidity exceeded 150 Klett units, the values were corrected as described by Sadler et al. (1980).

\section{$\underline{\text { Medium }}$}

The composition of the defined medium is given in Table 1 . When nitrite was used, it was autoclaved separately. Concentrated stock solutions of thiamine hydrochloride, ferrous sulfate (both made up in $10^{-3} \mathrm{~N} \mathrm{HCl}$ ) and methionine, dissolved in distilled water, were sterilized by filtration, using a Nalgene 20- $\mu \mathrm{m}$ Type S filter unit. Appropriate aliquats of these solutions were added immediately before starting a growth experiment.

Thiamine was purchased from CalBioChem. Corp. Betaine, vitamin $\mathrm{B}_{12}$, and methionine were obtained from the Sigma Chemical Company. The yeast extract was obtained from Difco.

\section{RESULTS}

As shown in Table 2, no aerobic growth was observed in the basal salts-1actate medium in the absence of yeast extract. Neither ashed yeast extract nor a mixture of amino acids replaced yeast extract. Of the various vitamins reported present in yeast extract (Culture Media Ingredients, Form No. CMI-1, Baltimore Biological Laboratories), only thiamine was effective. When thiamine was present in excess, the final turbidity observed in the defined medium was considerably lower than 
that observed in the presence of $0.01 \%$ yeast extract (Table 2). The addition of the other vitamins present in yeast extract, alone or in combination, did not increase the cell yield. Of various trace metals tested, only ferrous sulfate increased the cell yield, approaching those values observed in the presence of yeast extract (Table 2). Nitrate did not replace ammonium as the sole source of nitrogen, indicating that P. halodenitrificans lacked an assimilatory nitrate reductase. The generation time for aerobic growth in the defined medium was $2.5 \mathrm{~h}$; it was $1.5 \mathrm{~h}$ when $\mathrm{P}$. halodenitrificans was grown in complex medium (Sadler et al. 1980). Stock cultures have been maintained on agar slants of this defined medium for over a year.

The basal salts-lactate medium, containing thiamine and ferrous sulfate, did not support anaerobic growth in the absence of yeast extract. Of the various amino acids tested, only methionine replaced yeast extract (Table 2). As in the case of aerobic growth, the addition of ferrous sulfate also increased the cell yield. The defined medium designed for anaerobic growth supported a much higher population of cells than did the yeast extract-containing basal salts-lactate solution. The generation time during anaerobic growth was $4 \mathrm{~h}$ when the cells were grown in the presence of nitrate, and $7 \mathrm{~h}$ in the presence of nitrite. P. halodenitrificans also grew anaerobically in the presence of nitrous oxide with a generation time of $21 \mathrm{~h}$ (Hochstein, Kritikos, and Betlach, unpublished data). No growth was observed when the concentration of nitrite was greater than $29 \mathrm{mM}$. Although $\mathrm{P}$. halodenitrificans grows over a wide range of salt concentrations $(0.4$ to $3.0 \mathrm{M})$ in complex medium (Robinson and Gibbons 1952), the range of NaCl concentrations permitting 
either aerobic or anaerobic growth in synthetic medium was more limited (1 $\mathrm{M}$ to $2 \mathrm{M}$ ).

The requirement for methionine was not satisfied by aspartate, isoleucine, threonine, homocysteine, homoserine, dimethylglycine (alone or in combination with homoserine or homocysteine), sarcosine, serine, glycine, formate or formaldehyde. All of these are potential intermediates in the biosynthesis of methionine. Betaine or vitamin $\mathrm{B}_{12}$ replaced methionine (Table 2). The growth rates in the presence of betaine or vitamin $B_{12}$ were the same as those observed with methionine (data not shown). In terms of cell yield, betaine and methionine were equally effective on a molar basis, and vitamin $B_{12}$ was about 300 times more effective than either. At times, choline substituted for methionine, but the results were inconsistent.

Various carbohydrates were used as carbon sources for aerobic and anaerobic growth (Table 3). Several interesting patterns were observed. Al. of the hexoses tested, with the exception of mannose, were used. Mannitol was used aerobically and anaerobically, whereas sorbitol was not metabolized. P. halodenitrificans also used a variety of dissacharides, including sucrose, lactose, and maltose. Growth in the presence of carbohydrates resulted in an acidification of the growth medium during aerobic growth and, with the exception of fructose, anaerobic growth. When acid was produced, the final $\mathrm{pH}$ was 6.5 . A considerable amount of acid must have been produced during anaerobic growth, since the reduction of $1 \%$ nitrate to volatile products as a consequence of denitrification would have resulted in a marked alkalinization of the medium. The production of acid was unexpected, since the $\underline{P}$. halodenitrificans is described as not producing acid from glucose during aerobic growth 
(Duodoroff 1974). However, since those results were probably obtained from growth carried out in complex medium, acid production could have been masked by deamination. In addition to carbohydrates, a number of other compounds served as carbon sources. Of the amino acids tested (and listed in Table 3), aspartate was the only one that did not serve as a source of carbon.

\section{DISCUSSION}

The observation that $\underline{P}$. halodenitrificans grew in a simple mineralsalts medium containing thiamine and a suitable carbon source confirmed the earlier observation made by Flannery. However, the growth requirements were far less complex than suggested by his medium formulation, which consisted of 18 amino acids, 10 vitamins, various salts, as well as adenine, guanine, and uracil. The requirement for thiamine was remarkable. When cells were grown aerobically in defined medium containing $5 \mathrm{pg}$ thiamine $\mathrm{ml}^{-1}$, populations of $6 \times 10^{8}$ colony forming units $\mathrm{ml}^{-1}$ were obtained. When thiamine was present in excess, the numbers were of the order of $10^{10}$ colony forming units $\mathrm{ml}^{-1}$. These populations were similar to those observed in the complex medium (Sadler, Kritikos, and Hochstein, unpublished data).

The defined medium did not support anaerobic growth in the absence of methionine. Methionine is synthesized from aspartate in a reaction sequence which terminates in the methylation of homocysteine. In certain instances, serine is the precursor of this methyl group, which is formed in a series of reactions whereby the hydroxymethyl carbon of serine is transferred to tetrahydrofolate resulting, ultimately, in 
methyl tetrahydrofolate (Taylor and Weissbach 1973). This methyl group is transferred to homocysteine by a set of reactions, some of which require a cobalamin coenzyme (Woods et al. 1965). Betaine may also serve as a methyl donor in bacterial systems, presumably by the betaine-homocysteine methyltransferase reaction (White et al. 1973).

The ability of betaine but not homocysteine to replace methionine suggests a defect in the synthesis of methyl groups. However, since vitamin $B_{12}$ replaced methionine, anaerobically growing cells must have been able to make and transfer methyl groups. The alternative conclusion is that the methionine requirement reflected a defect in the synthesis of the cobalamin coenzyme. Since betaine replaced methionine, anaerobic cells must also have been defective in the synthesis of betaine, at least at rates appropriate to cellular needs. This would be consistent with our observation that choline, from which betaine can be derived by oxidation via betaine aldehyde (Kensler and Langermann 1954), did not substitute effectively for methionine. Furthermore, choline, which served as the sole source of carbon for aerobic growth, was ineffective for anaerobic growth (Table 3).

The nutritional requirements exhibited by $\underline{p}$. halodenitrificans indicate that the organism potentially has two pathways for synthesizing methionine: one involves betaine and, if functional, is so only during aerobic growth; the other is the cobalamin-dependent pathway. Whether this pathway operates during aerobic growth is uncertain. If P. halodenitrificans synthesized betaine from choline, the observation that choline at times replaced methionine could have reflected the presence of sufficient oxygen in the growth medium at the initiation 
of growth so that choline was oxidized to growth-supporting levels of betaine.

Little is known about the synthesis of betaine in bacteria. P. halodenitrificans may prove useful in studying the biosynthesis of betaine as well as the pathway associated with the production of the metabolically active form of the cobalmin coenzyme concerned with methionine biosynthesis.

\section{ACKNOWLEDGMENTS}

We wish to acknowledge the technical assistance of Kathleen Grant Gonzales, Michael Trindle, and Brian Wilson.

This work was supported, in part, by funds from the NASA/University Consortium Agreement NCA-OR 685902. 
References

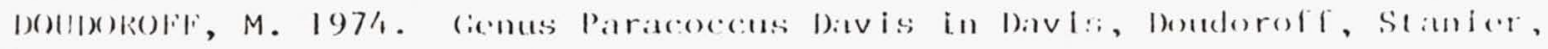
and Mande1 1969, 384. In Bergey's Manual of Determinative Bacteriology, 8th ed. Edited by R. E. Buchanan and N. E. Gibbons. The Williams and Wilkens Co., Baltimore, pp. 438-440.

FORSYTH, M. P. and D. J. KUSHNER. 1970. Nutrition and distribution of salt response in populations of moderately halophilic bacteria. Canad. J. Microbiol. 16: 253-261.

HOCHSTEIN, L. I. and B. P. DALTON. 1968. Salt specificity of a reduced nicotinamide adenine dinucleotide oxidase prepared from a halophilic bacterium. J. Bacterio1. 25: 37-42.

KENSLER, C. J. and H. LANGERMANN. 1954. Metabolism of choline and related compounds by hepatic tissue from several species including man. Proc. Soc. Exp. Biol. Med. 85: 364-367.

ROBINSON, J. and N. E. GIBBONS. 1952. The effect of salts on the growth of Micrococcus halodenitrificans n. sp. Canad. J. Bot. 30: $147-154$.

ROSSO, J. P., P. FORGET, and F. PICHINOTY. 1973. Les nitratereductases bacteriennes solubilisation, purification et properties de I'enzyme a de Micrococcus halodenitrificans. Biochim. Biophys. Acta 321: 443-455.

SADLER, M., M. McANINCH, R. ALICO, and L. I. HOCHSTEIN. 1980. The intracellular $\mathrm{Na}^{+}$and $\mathrm{K}^{+}$composition of the moderately halophilic bacterium, Paracoccus halodenitrificans. Canad. J. Microbiol. 26: 496-502. 
TAYLOR, R. T. and H. WEISSBACH. 1973. N5-methyltetrahydrofolatehomocysteine methyltransferases. In The Enzymes, Vol. 9, 3rd ed., Edited by P. D. Boyer. Academic Press, New York, pp. $121-165$.

WHITE, R. F., L. KAPLAN, and J. BIRNBAUM. 1973. Betaine-homocysteine transmethylase in Pseudomonas denitrificans, a vitamin $B_{12}$ overproducer. J. Bacteriol. 113: 218-223.

WOODS, D. D., M. A. FOSTER, and J. R. GUEST. 1965. Cobalamin-dependent and -independent methyl transfer in methionine biosynthesis. In Transmethylation and Methionine Biosynthesis. Edited by S. K. Shapiro and F. Schlenk. University of Chicago Press, Chicago, pp. 138-156. 
TABLE 1. Composition of the defined medium for $P$. halodenitrificans

\begin{tabular}{|c|c|}
\hline $\mathrm{NaCl}$ & $58.4 \mathrm{~g}$ \\
\hline $\mathrm{K}_{2} \mathrm{HPO}_{4}$ & $8.7 \mathrm{~g}$ \\
\hline$\left(\mathrm{NH}_{4}\right)_{2} \mathrm{SO}_{4}$ & $1.0 \mathrm{~g}$ \\
\hline $\mathrm{MgSO}_{4} \cdot 7 \mathrm{H}_{2} \mathrm{O}$ & $0.1 \mathrm{~g}$ \\
\hline Sodium lactate ${ }^{a}$ & $5.0 \mathrm{~g}$ \\
\hline Thiamine hydrochloride & $0.05 \mathrm{mg}$ \\
\hline $\mathrm{FeSO}_{4} \cdot 7 \mathrm{H}_{2} \mathrm{O}$ & $0.03 \mathrm{mg}$ \\
\hline L-methionine $e^{b}$ & $14.0 \mathrm{mg}$ \\
\hline $\mathrm{KNO}_{3}\left(\text { or } \mathrm{KNO}_{2}\right)^{\mathrm{b}}$ & 10 (or 2.5$) \mathrm{g}$ \\
\hline Water & 1 liter \\
\hline
\end{tabular}

Note: The $\mathrm{pH}$ was adjusted to 7.4.

added as $8.3 \mathrm{ml}$ of a $60 \%$ solution of sodium lactate.

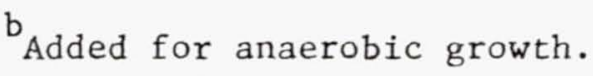


TABLE 2. Growth requirements of $P$. halodentrificans

\begin{tabular}{lcr}
\multicolumn{1}{c}{ Medium } & \multicolumn{1}{c}{ Klett units } \\
\cline { 2 - 3 } & Aerobic $^{\text {a }}$ & Anaerobic \\
\hline Basal salts plus lactate & 0 & 0 \\
Basal salts, lactate, plus & 1200 & 157 \\
$0.01 \%$ yeast extract & 145 & 53 \\
$0.0001 \%$ yeast extract & 250 & 0 \\
thiamine & 1100 & 280 \\
thiamine, FeSO 4 \\
thiamine, methionine
\end{tabular}

NOTE: The reported changes in Klett units were obtained by interpolating the turbidity increase occurring during the stationary phase through the extrapolated value of the exponential growth phase. The initial Klett values were subtracted from the value observed at the intersection of the lines. The concentrations of the added ingredients were those in Table 1. Anaerobic growth was carried out in the presence of $1 \%$ potassium nitrate. Betaine and vitamin $\mathrm{B}_{12}$ were added to a final concentration of $15.5 \mathrm{mg}$ and $0.4 \mathrm{mg} /$ liter, respectively. $a_{\text {nd }}=$ not done. 
TABLE 3. Substrates supporting growth in the defined medium

\begin{tabular}{ll} 
Acetate & Glycine $^{a}$ \\
B-Alanine & Lactate \\
Arginine & Malate \\
Choline & Maltose \\
Citrate & Mannitol \\
Dimethylglycine & Proline \\
Ethanol & Propanol \\
Fructose & Succinate \\
Galactose & Sucrose \\
Glucose & Trehalose \\
Glycerol & Sarcosine \\
\hline
\end{tabular}

NOTE: Each compound was tested for its ability to support growth in the defined medium at a concentration of $0.5 \%$, with the appropriate additions for aerobic or anaerobic growth as indicated in Table 1. All of the amino acids were the L-isomers. The following compounds did not support either aerobic or anaerobic growth: arabinose, arabitol, aspartate, betaine, butanol, formate, mannose, methanol, methionine, ribitol, ribose, or sorbitol.

${ }^{a}$ Supported only aerobic growth. 


\begin{tabular}{|c|c|c|c|}
\hline $\begin{array}{l}\text { 1. Report No. } \\
\text { NASA TM-84411 }\end{array}$ & 2. Government Accession No. & \multicolumn{2}{|c|}{ 3. Recipient's Catalog No. } \\
\hline \multirow{2}{*}{\multicolumn{2}{|c|}{$\begin{array}{l}\text { 4. Title and Subtitie } \\
\text { THE GROWTH OF PARACOCCUS HALODENITRIFICANS IN A } \\
\text { DEFINED MEDIUM }\end{array}$}} & \multicolumn{2}{|c|}{$\begin{array}{l}\text { 5. Report Date } \\
\text { October } 1983\end{array}$} \\
\hline & & \multicolumn{2}{|c|}{ 6. Performing Organization Code } \\
\hline \multicolumn{2}{|c|}{$\begin{array}{l}\text { 7. Author(s) Lawrence I. Hochstein and Geraldine A. } \\
\text { Tomlinson (Dept. of Biology, University of Santa } \\
\text { Clara, Santa Clara, California 95053) }\end{array}$} & \multicolumn{2}{|c|}{$\begin{array}{l}\text { 8. Performing Organization Report No. } \\
\mathrm{A}-9487\end{array}$} \\
\hline \multirow{2}{*}{\multicolumn{2}{|c|}{$\begin{array}{l}\text { 9. Performing Organization Name and Address } \\
\text { Ames Research Center } \\
\text { Moffett Field, California } 94035\end{array}$}} & \multicolumn{2}{|c|}{$\begin{array}{l}\text { 10. Work Unit No. } \\
\text { T-4615 }\end{array}$} \\
\hline & & \multicolumn{2}{|c|}{ 11. Contract or Grant No. } \\
\hline \multirow{2}{*}{\multicolumn{2}{|c|}{$\begin{array}{l}\text { 12. Sponsoring Agency Name and Address } \\
\text { National Aeronautics and Space Administration } \\
\text { Washington, D.C. } 20546\end{array}$}} & \multicolumn{2}{|c|}{$\begin{array}{l}\text { 13. Type of Report and Period Covered } \\
\text { Technical Memorandum }\end{array}$} \\
\hline & & \multicolumn{2}{|c|}{ 14. Sponsoring Agency Code } \\
\hline \multicolumn{4}{|c|}{$\begin{array}{l}\text { 15. Supplementary Notes } \\
\text { Point of Contact: L. I. Hochstein, Ames Research Center, M/S 239-10, Moffett } \\
\text { Field, California } 94035 \text { (415) } 965-5938 \text { or FTS 448-5938. }\end{array}$} \\
\hline \multicolumn{4}{|c|}{$\begin{array}{l}\text { 16. Abstract } \\
\text { A synthetic medium, consisting of inorganic salts and any of a number of } \\
\text { carbon sources, supported the aerobic growth of Paracoccus halodenitrificans } \\
\text { when supplemented with thiamine. The same medium plus a nitrogenous oxide } \\
\text { supported anaerobic growth when additionally supplemented with methionine. } \\
\text { The observation that vitamin } \mathrm{B}_{12} \text { or betaine replaced methionine suggested } \\
\text { that P. halodenitrificans had a defect in the cobalamin-dependent pathway for } \\
\text { methionine biosynthesis, as well as the inability to synthesize betaine when } \\
\text { growing anaerobically. }\end{array}$} \\
\hline \multicolumn{4}{|c|}{$\begin{array}{l}\text { 17. Key Words (Suggested by Author(s)) } \\
\text { P. halodenitrificans } \\
\text { Synthetic medium } \\
\text { Methyl group } \\
\text { Biosynthesis }\end{array}$} \\
\hline $\begin{array}{l}\text { 19. Security Cassif. (of this report) } \\
\text { Unclassified }\end{array}$ & $\begin{array}{l}\text { 20. Security Classif. (of this page) } \\
\text { Unclassified }\end{array}$ & $\begin{array}{c}\text { 21. No. of Pages } \\
16\end{array}$ & $\begin{array}{l}\text { 22. Price } \\
\text { A02 }\end{array}$ \\
\hline
\end{tabular}

- For sale by the National Technical Information Service, Springfield, Virginia 22161 